\title{
THE EFFECT OF RUPIAH EXCHANGE RATE AND INFLATION RATE TOWARDS COMPOSITE STOCK PRICE INDEX IN INDONESIA STOCK EXCHANGE
}

\author{
Apituley Margaretha Rosalyn \\ Economic Development Study Program, Faculty of Economics, \\ Christian University of Indonesia, Maluku \\ *E-mail: rapituley@yahoo.com
}

\begin{abstract}
This study aims to examine the relationship between the rupiah exchange rate and inflation rates on CSPI in Indonesia Stock Exchange. The data used are secondary data of Rupiah exchange rate toward US Dollar and inflation rate data obtained from Bank Indonesia publication through www.bi.go.id website and movement data of CSPI through website www.finance.yahoo.com. Determination of the sample based on monthly time series data period December 2011 - January 2014 by using the method of saturated samples, i.e. as many as 48 samples. The data obtained were analyzed by multiple linear regression approaches. There was a negative influence of inflation rate on CSPI for the period of December 2011 - January 2014 with the regression coefficient of 0.279 ; the negative value indicates that there is a negative correlation of inflation rate to CSPI. While the relationship between the Rupiah exchange rate To CSPI showed a positive relationship with the regression coefficient of 0.888 .
\end{abstract}

\section{KEY WORDS}

Rupiah exchange rate, inflation rate, composite stock price index, prices.

Investment is a way of investment either directly or indirectly which aims to obtain a certain income as a result of the investment. Currently, investment in the capital market has been ogled many investors (Astuti, et al, 2013). Septyanto (2013) mentions that the capital market as a vehicle for the financial sector outside banks provides funds for businesses through the sale of shares, bonds, and derivatives. Theoretically, the rate of economic growth is positively correlated with investment. The economic growth of a country cannot be separated from the capital market itself which is measured in the Composite Stock Price Index (CSPI). The stock price index is a door, is the beginning of consideration to make an investment, because of the stock price index is known to the situation in general (Astuti, et al, 2013). The $\mathrm{JCl}$ describes a series of historical information about composite share price movements, up to a certain date. Usually, the stock price movements are presented daily based on the closing price on the stock exchange on the day. The index is presented for a certain period. The CSPI reflects a value that serves as a measure of the performance of a joint stock in the stock exchange (Taufiq and Kefi, 2015).

The Composite Stock Price Index is a reflection of the Indonesian economy when the CSPI shows a significant increase in the Indonesian economy is in a conducive condition and vice versa. To be able to find out what can help the movement of CSPI should be considered several factors such as SBI interest rate, inflation, rupiah exchange rate and global exchange like Dow Jones index (Sudarsana \& Candraningrat, 2014). Economic growth is the development of activities in the economy that cause goods and services produced by the community increases. The Central Bureau of Statistics (BPS) reported that gross domestic product (GDP) or Indonesia's economic growth during 2017 reached 5.07 percent. This figure, according to BPS, is the highest economic growth figure since 2014. The growth of a country's investment will be affected by the level of economic growth in the country. The participation of Bank Indonesia in capital market or stock exchange aims to enable banks to have financial and fundamental support whereby it is essential for the sustainability of the bank itself (Parulian, et al, 2013). Currently, Bank Indonesia uses the SBI rate as one of the 
instruments to control inflation. If inflation is felt high enough, Bank Indonesia will raise the SBI interest rate to reduce inflation (Nurwani, 2010).

The exchange rate is a very important economic indicator because the movement of the exchange rate has the wide effect on the economic aspect of a country. Currently the development of the economic system in a more open direction between countries. The exchange rate plays a vital role in the trading level of a country, which is the most critical for the majority of the free market economy in the world. The open economy is the occurrence of international trade between countries in the world. The existence of currency differences used in both importing and exporting countries will result in a difference in the exchange rate. The difference in the exchange rate of a country is principally determined by the amount of demand and supply of the currency (Krugman, 2005). The importance of exchange rate as one economic indicator makes it interesting to discuss and see the changes or fluctuations that can be influenced by various factors.

The ability of investors to understand and forecast future macroeconomic conditions will be very useful in making profitable investment decisions (Tandellin, 2007: 211). Information on the stock price index, stock price performance, corporate financial statements, etc., where such information data can be obtained through IDX (Indonesia Stock Exchange). Investment through the capital market in addition to providing results also has a level of risk that must be borne. If investments in the Stock Exchange can be carefully managed, it will bring far greater profits than investments in savings and time deposits. Steps that need to be done in minimizing the risk of investing in the capital market, investors must understand the investment well (Metro, 2015).

The view that low inflation is an important requirement for sustained economic growth became accepted after the great depression in the 1930s. Thus, low inflation is always considered as an objective of economic policy, it has been shown that volatility reduces economic growth and is worthy of our attention (Klomp and Haan, 2009). Inflation is a situation where there is excess demand for goods and services as a whole. Inflation has a negative and positive impact. In general, the impact of inflation may affect the distribution of income, allocation of production factors and national production, often in Indonesia inflation has a negative impact (Saputra and Nugroho, 2014). Factors affecting the inflation rate in Indonesia are interest rates, rising commodity prices and swings in foreign debt due to the depreciation of the US dollar and other foreign currencies (Panjaitan and Wardoyo, 2016). thus it is necessary to examine the factors that influence the movement of CSPI in Indonesia stock exchanges. According to Hussain, \& Malik (2011) that the causality that runs from inflation rate to economic growth is an indication of the relationship that inflation indeed has an impact on growth. The relationship between inflation and economic growth under the costbased price approach (Baltar, 2014).

The most important economic measures are monetary. They have many different names, are derived in different theories and employ different formulas; yet, they all attempt to do the same thing: to separate a change in nominal value into a 'real part' due to the changes in quantities and an inflation due to the changes in prices. Examples are real national product and its components, the GNP deflator, the CPI, various measures related to consumer surplus, as well as a large number of formulas for price and quantity indexes that have been proposed. The theories that have been developed to derive these measures are largely unsatisfactory. The axiomatic theory of indexes does not make clear which economic problem a particular formula can be used to solve. The economic theories are for the most part based on unrealistic assumptions (Hillinger, 2008).

\section{METHODS OF RESEARCH}

This research is a study of empirical studies conducted on the stock exchanges of Indonesia. The object of this research is the data of rupiah exchange rate and inflation rate. The data used are secondary data of Rupiah exchange rate to US Dollar and Inflation rate data obtained from Bank Indonesia publication through www.bi.go.id website and movement data of CSPI obtained through website www.finance.yahoo.com. Determination of sample 
based on monthly time series data for period of December 2011 - January 2014 by using the method of the saturated sample, which is counted 48 samples. The data obtained were analyzed by multiple linear regression approach.

\section{RESULTS AND DISCUSSION}

Regression approach is used in this research to test the influence of inflation and rupiah exchange rate toward CSPI.

Table 1 - Simultaneous Test Results of Inflation rate and Rupiah Exchange Rate on CSPI

\begin{tabular}{|cccccc|}
\hline Model & Sum of Squares & df. & Mean Square & F & Sig. \\
\hline Regression & 28.250 & 2 & 14.125 & 33.899 & $.000^{\mathrm{a}}$ \\
Residual & 18.750 & 45 & .417 & & \\
Total & 47.000 & 47 & & & \\
\hline $\mathrm{R}=0.775 ; \mathrm{R}^{2}=0.601 ;$ Adj. $\mathrm{R}^{2}=0.583$; Std. Error $=0.645$ & & & \\
\hline
\end{tabular}

Table 1 presents the model summary and Regression Analysis of Variance (ANOVA). From the table, the multiple correlation $\mathrm{R}$ Square $=0.601$, indicates that the model accounts for only $60.10 \%$ of the variance in CSPI, can be described by variations in change Inflation rate and Rupiah Exchange Rate, while the rest $30.9 \%$ is described by other variables which are not analyzed on this model.

The result of hypothesis test simultaneously shows that the inflation rate and the rupiah exchange rate simultaneously have the significant effect on $\operatorname{CSPI}(F(2,45)=33.89, p$ $<0.05)$. This result shows that the inflation rate and the rupiah exchange rate can predict CSPI simultaneously. Partial test results are shown in Table 2:

Table 2 - Partial Test Results of Inflation Rate and Rupiah Exchange Rate on CSPI

\begin{tabular}{|c|c|c|c|c|c|c|}
\hline \multirow{2}{*}{\multicolumn{2}{|c|}{ Model }} & \multicolumn{2}{|c|}{ Unstandardized Coefficients } & \multirow{2}{*}{$\frac{\text { Standardized Coefficients }}{\text { Beta }}$} & \multirow{2}{*}{$\mathrm{t}$} & \multirow{2}{*}{ Sig. } \\
\hline & & $\mathrm{B}$ & Std. Error & & & \\
\hline \multirow{3}{*}{1} & (Constant) & $6.516 \mathrm{E}-16$ & .093 & - & .000 & 1.000 \\
\hline & Zscore(Rupiah Exchange Rate) & .888 & .111 & .888 & 7.968 & .000 \\
\hline & Zscore(Inflation rete) & -.279 & .111 & -.279 & -2.503 & .016 \\
\hline
\end{tabular}

Regression analysis results show that there is a significant influence Inflation rate to CSPI ( $\beta=-.279, p=0.016)$ as well as the effect of rupiah exchange rate on CSPI ( $\beta=.888$, $p=0,00$ ) Result of significance test based on the regression model obtained the magnitude of the coefficient of inflation rate effect on the CSPI of 0.279 . Regression coefficient indicates that if the inflation rate increased one unit then CSPI decreased by 0.279 where the rupiah exchange rate variable is assumed constant. Coefficient of exchange rate regression equal to 0.888 . Regression coefficient a positive the value indicates that if the rupiah exchange rate rises by one unit then CSPI increases by 0.888 where the variable rate of inflation is assumed to be constant.

Effect of Rupiah Exchange Rate toward Composite Stock Price Index (CSPI). The result of the analysis shows that rupiah exchange the rate has the positive and significant effect to CSPI. This is in accordance with research conducted Nurwani (2010) which states that the exchange rate of rupiah has a positive and significant impact on the movement of composite stock price index. The exchange rate is often called the exchange rate (ex-change rate) is the amount of a particular currency that can be exchanged against one unit of another currency. The rupiah exchange rate against other currencies has an effect on the profit of a company, because the company using the production materials from abroad will experience an increase in the value of the debt if the value of the rupiah against the value of foreign currency decreased or depreciated, the exchange rate is very influential for companies that want to do investment (Putri, 2017).

Unlike the research conducted by Astuti, et al (2013), the rupiah exchange rate against the US dollar influences CSPI which can be seen from the result of significant and negative 
influence on CSPI, so if the exchange rate (Exchange) Rupiah to Dollar has increased, decline and vice versa. Research conducted by Jayanti, et al (2014) also states that the rupiah exchange rate partially has a negative and significant influence on CSPI. Other research mentioned that the exchange rate of Rupiah has no significant the effect to CSPI listed in Indonesia Stock Exchange period 2011-2015 period, when there is a weakening of Rupiah exchange rate to US Dollar, Rupiah exchange rate can still stay in the range of Rp $10,819.32$, the US economy in the midst of global crisis makes investors have confidence in the capital market in Indonesia despite the weakening of US Dollar and this condition is not very influential on CSPI (Salsabila, et al, 2016).

Appa Research (2014) shows that the appreciation of the rupiah exchange rate or the US dollar has a positive and significant effect on CSPI, the depreciation of the rupiah exchange rate against the US dollar has caused the stocks of import-oriented companies to decline which affects the declining interest of investors to invest in the capital market, so that companies using imported materials suffered losses due to higher production costs than the selling price of the product. This condition causes the decline in the value of CSPI in the stock exchange because investors are more interested in the shares of companies that have increased.

According to Joesoef (2008: 25) "the way the valuation of currency prices by declaring the many units of local currency required to obtain a unit of foreign currency called direct quotation". The formula for calculating direct quotation is as follows:

$$
\text { Direct Quotation }=\frac{\text { the number of units of local currencl }}{\text { one unit of foreign currency }}
$$

The decline in the rupiah exchange rate against foreign currencies (US dollar) has an impact on the rising cost of imported raw materials and equipment required by issuers resulting in higher production costs, in addition to the many issuers that have foreign debt so that the increase in the exchange rate will increase the debt burden borne by the issuer.

Effect of Inflation Rate Toward Composite Stock Price Index (CSPI). The result of the analysis shows that there is a negative and insignificant effect of rupiah inflation on CSPI. This is in accordance with Taufiq and Kefi (2015) research which shows that inflation has a negative and significant effect on CSPI. Inflation is very influential on the economy, Marunung (2016) states that Inflation is a tendency to raise prices continuously or can be interpreted as a decline in value of money as a whole, the higher price increases, and the more the value of money. The result of research (Tabi and Ondoa, 2011) It is shown that increase in money supply increase growth and that growth causes inflation; however, an increase in money supply does not necessarily increase inflation.

In contrast to research Maurina, et al (2015) inflation has a positive but insignificant effect on CSPI, this is because during the period of observation the inflation rate is in the category of mild inflation because it is below $10 \%$, so the results show that the inflation rate is not a determinant factor in explaining CSPI. The company may charge the cost increase to the consumer with a larger proportion so that the company's profits increase and will increase the company's ability to pay dividends and will provide a positive assessment on stock prices, so that investor interest to invest in stocks will increase and CSPI will increase.

Research Putri (2016) that partially inflation has a negative and insignificant effect on CSPI in the period 2011-2013, because of the rise of inflation into a negative signal for investors to invest in capital markets tend to release shares to switch investments in other forms, such as savings or deposits because assuming a higher risk, so switching investment in other forms will cause investors to make sales, thus lowering stocks and CSPI.

Inflation can cause adverse effects of decreasing the level of public welfare and worsening the distribution of income, people are reluctant to save, it can be profitable if the income earned is higher than the increase in production costs, long-term development prospects are getting worse and investment is decreasing (Appa, 2014). In addition, inflation can also have a positive impact, if inflation is mild it can encourage a better economy, which can increase national income and make people excited to work harder, save and invest 
(Divianto, 2013). Inflation in 2013 was the highest since 2008, the crisis which reached $11.06 \%$. That figure is an accumulation of previous inflation due to rising fuel prices. As for core inflation in December 2013 recorded $0.45 \%$, core inflation year to date and year on year respectively $4.98 \%$.

\section{CONCLUSION AND RECOMMENDATIONS}

Based on the results and discussion in this study can conclude that there is a negative effect of inflation rate on the Composite Stock Price Index (CSPI) period December 2011 January 2014 with a large influence of 0.279 , a negative value indicates that there is a negative relationship inflation rate to CSPI. While the relationship between the rupiah exchange rate against CSPI shows a positive relationship of 0.888 . These results suggest that the higher the rupiah exchange rate will increase CSPI. While inflation increases can decrease CSPI.

The results of this study provide recommendations For investors who want to invest in CSPI shares, it is advisable to better consider the information coming from within the country such as inflation rate and the rupiah exchange rate as indicators coming from abroad such as the index of capital markets of other countries. Such information is needed to predict the CSPI fluctuations needed for proper decision making. In addition, further research on the Composite Stock Price Index (CSPI), it is suggested to add or use other internal indicators such as GDP, the amount of money in circulation, the development of imported exports and factors originating from abroad (such as world gold prices, world oil prices, and other countries' stock indexes.

\section{ACKNOWLEDGMENTS}

The author thanks to the University of Christian Maluku for facilitated this research.

\section{REFERENCES}

1. Appa, Y. (2014). Pengaruh Inflasi dan Kurs Rupiah/Dolar Amerika terhadap Indeks Harga Saham Gabungan (IHSG) di Bursa Efek Indonesia (BEI). Jurnal ISSN, 2355-5408.

2. Amin, M. Z. (2012). Pengaruh Tingkat Inflasi, Suku Bunga SBI, Nilai Kurs Dollar (USD/IDR), dan Indeks DowJones (DJIA) Terhadap Pergerakan Indeks Harga Saham Gabungan Di Bursa Efek Indonesia (BEI)(Periode 2008-2011)

3. Astuti, R., Prihatini, A. E., dan Susanta, H. 2013. Analisis Pengaruh Tingkat Suku Bunga (SBI), Nilai Tukar (Kurs) Rupiah, Inflasi, dan Indeks Bursa Internasional terhadap IHSG (Studi Pada IHSG di BEI Periode 2008-2012). Jurnal IImu Administrasi Bisnis, 2(4), 136145.

4. Baltar, C. T. (2014). Inflation and economic growth in an open developing country: the case of Brazil. Cambridge Journal of Economics, 39(5), 1263-1280.

5. Candra, C. (2015). Pengaruh Kurs (Usd/Idr), Suku Bunga Sbi, Dan Tingkat Inflasi Terhadap Indeks Harga Saham Gabungan Yang Tercatat Dalam Bursa Efek Indonesia. Artikel Mahasiswa 2015

6. Divianto. (2013). Analisis Pengaruh Tingkat Inflasi, Tingkat Suku Bunga SBI, dan Nilai Kurs Dollar As (USD) Terhadaplndeks Harga Saham Gabungan (lhsg) Di Bursa Efek Indonesia. Jurnal Ekonomi dan informasi Akutasi. 3(2) 165-197

7. Hillinger, C. (2008). Measuring real value and inflation. Economics The open accsess, open Asseement E-Journal, Vol. 2(6) 1-28.

8. Hussain, S., \& Malik, S. (2011). Inflation and economic growth: Evidence from Pakistan. International Journal of Economics and Finance, 3(5), 262.

9. https://ekonomi.kompas.com/read/2018/02/05/113820026/ekonomi-indonesia-2017tumbuh-507-persen-tertinggi-sejak-tahun-2014. 30 Mei 2018.

10. Jayanti, Y. (2014). Pengaruh Tingkat Inflasi, Tingkat Suku Bunga SBI, Nilai Tukar Rupiah, Indeks Dow Jones, Dan Indeks Klse Terhadap Indeks Harga Saham Gabungan 
(Ihsg) Studi Pada Bursa Efek Indonesia Periode Januari 2010-Desember 2013. Jurnal Administrasi Bisnis, 11(1).

11. Joesoef, Jose Rizal. (2008). Pasar Uang dan Pasar Valuta Asing. Jakarta : Salemba Empat.

12. Klomp,J., and Haan, J. (2009). Political institutions and economic volatility. European Journal of Political Economy,25 (2009), 311-326. doi:10.1016/j.ejpoleco.2009.02.006, http://dx.doi.org/10.1016/j.ejpoleco.2009.02.006

13. Krugman. 2005. Ekonomi Internasional Teori dan Kebijakan. Jilid 2. Edisi 5. PT Indeks Kelompok Gramedia.

14. Liauw, J dan Wijaya. (2013). Analisis Pengaruh Tingkat Inflasi, Tingkat Suku Bunga SBI dan Nilai Tukar Rupiah Terhadap Indeks Harga Saham Gabungan (IHSG) di Bursa Efek Indonesia.

15. Manurung, R. (2016). Pengaruh Inflasi, Suku Bunga Dan Kurs Terhadap Indeks Harga Saham Gabungan Pada Bursa Efek Indonesia. Jurnal Ekonomi, 19(4)148-156

16. Maurina, Y., Hidayat dan Sulasmiyati. (2015). Pengaruh Tingkat Inflasi, Kurs Rupiah Dan Tingkat Suku Bunga Bi Rate Terhadap Ihsg (Studi Pada Bursa Efek Indonesia Periode 2010-2014). Jurnal Administrasi Bisnis, 27(2).

17. Metro, D. F. E. U. M. (2015). Analisis Nilai Kurs Rupiah Dan Nilai Indonesia Crude Price (Icp) Serta Pengaruhnya Terhadap Indeks Harga Saham Gabungan (Ihsg) Ditengah Pemberlakuan Mea 2015. Jurnal Administrasi Bisnis, 27(2). Jurnal Magister Manajemen Vol 1 No. 2, Juli 2015

18. Nurwani. (2010). Analisis Pengaruh Inflasi, Nilai Tukar Rupiah, Dan Suku Bunga Sbi Terhadap Pergerakan Indeks Harga Saham Gabungan Di Bursa Efek Indonesia. Universitas Muhammadiyah. Sumatra Utara

19. Panjaitan dan Wardoyo. (2016). Faktor-faktor yang Mempengaruhi Inflasi di Indonesia. Jurnal Ekonomi Bisnis. 21(3) 182-193

20. Parulian, Y. H., Subartini, B., \& Riaman, R. (2013). Analisis Pengaruh IHSG, Inflasi, BI Rate dan Nilai Tukar Rupiah terhadap Fluktuasi Harga Saham Bank Di Indonesia Menggunakan Metode Regresi Linear Berganda. Jurnal Matematika Integratif, 9(1), 1928.

21. Pratama, H., \& Maryatmo, R. (2015). Pengaruh Inflasi, Kurs Rp/Dollar Usa, Dan Suku Bunga Kredit Terhadap Indeks Harga Saham Gabungan (Ihsg). http://ejournal.uajy.ac.id/8941/1/JURNAL.pdf.

22. Putri, A. A. (2016). Pengaruh Inflasi, Bi Rate, Dan Nilai Tukar (Kurs Usd/ldr) Terhadap Indeks Harga Saham Gabungan (Ihsg) Di Bursa Efek Indonesia (Bei) Periode Tahun 2011-2013. Indonesia Banking School.

23. Putri, L. P. (2017). Pengaruh Inflasi dan Nilai Tukar Rupiah Atas Dollar AS terhadap Kinerja Saham Perusahaan Property dan Real Estate di Indonesia. EKONOMIKAWAN: Jurnal IImu Ekonomi dan Studi Pembangunan, 17(1).

24. Salsabila, A., Isynuwardhana, D., dan Khairunnisa, K. (2016). Pengaruh Inflasi, Nilai Tukar/kurs (usd/idr), Dan Indeks Nikkei 225 Terhadap Indeks Harga Saham Gabungan Di Bursa Efek Indonesia. eProceedings of Management, 3(2).

25. Saputra, K., dan Nugroho, S. B. M. (2013). Analisis faktor-faktor yang mempengaruhi inflasi di Indonesia 2007-2012 (Doctoral dissertation, Fakultas Ekonomika dan Bisnis).

26. Septyanto, D. 2013. Faktor-Faktor yang Mempengaruhi Investor Individu dalam Pengambilan Keputusan Investasi Sekuritas di Bursa Efek Indonesia (BEI). Jurnal Ekonomi Universitas Esa Unggul, 4(2).

27. Sudarsana, N. M. A. D., \& Candraningrat, I. R. (2014). Pengaruh Suku Bunga SBI, Nilai Tukar, Inflasi Dan Indeks Dow Jones Terhadap Indeks Harga Saham Gabungan Di BEl. Jurnal Fakultas Ekonomi dan Bisnis Universitas Udayana (Unud), Bali, Indonesia. 32913308.

28. Tabi, H. N., \& Ondoa, H. A. (2011). Inflation, money and economic growth in Cameroon. International Journal of financial research, 2(1), 45.

29. Taufiq, M., \& Kefi, B. S. (2015). Pengaruh Inflasi, BI Rate dan Kurs Terhadap Indeks Harga Saham Gabungan. Jurnal Ekonomi Manajemen Akuntansi, 22(38). 